\title{
Coger: Islamic Charity Business to Alleviate Social Gap
}

\author{
Mohammad Hatta Fahamsyah ${ }^{1}$, Menur Kusumaningtyas ${ }^{2,3}$ \\ Universitas Pelita Bangsa $^{1}$ STIE Mahardhika Surabaya ${ }^{2}$, Universitas Airlangga ${ }^{3}$ \\ $\left\{\right.$ hatta@pelitabangsa.ac.id ${ }^{1}, \underline{\text { menur.kusumaningtyas@stiemahardhika.ac.id² }}$, \\ menur.kusumaningtyas-2019@feb.unair.ac.id $\left.{ }^{3}\right\}$
}

\begin{abstract}
This paper aims to identify some instruments are arranged in Islamic economics to solve social problems and reducing social inequality through a business model based Islamic social. Café Coger is an example of an Islamic business whose profits are managed for charity. This conceptual research is based on the Quran as the primary source as well as social welfare contemporary philosophy. This study proposes an efficient system of management of Islam that create business for the social benefit. Social implications in this study is effective in solving social problems, and reducing social inequality and creating independent businesses.
\end{abstract}

Keywords: Islamic Social Business, Islamic Business

\section{Introduction}

The tradition of drinking coffee every day has made Indonesia one of the best coffee producers in the world. West Java, as a calculated coffee producer, has been ranked sixth in the Specialty Coffee Association of America Expo. Not only is the choice more diverse, coffee prices also vary from very cheap to expensive. (Riad Diharja, 2018)

The difference between low prices and 'high end' coffees made by professional baristas is determined by the origin of coffee Brazil is known as a coffee producer with relatively average prices for milk-based coffee. Unlike Geisha coffee from Panama, it is known for its high floral taste. (Matthew Lewin Wins 2019 Australian Barista Championship! - ONA, n.d.)

Meanwhile, Indonesian coffee originating from Manglayang is included in the type of arabica coffee with a sweet and sour taste and thick vanilla, which grows in the plains of Mount Manglayang, West Java. Manglayang Coffee aims to become a welfare-based coffee plantation for farmer groups in the Palintang Cilarareun area, Cilengkrang District, Bandung Regency. This is the basis for Kedai Coger to collaborate with these farmers. The form of cooperation uses Islamic business where the distribution begins with the concept of halalan thoyiban, so that the business of Muslim farmers is not only profitable but also a blessing (Kopi Manglayang Tembus Pasar Maroko, Jepang, Australia - Ekonomi Bisnis.Com, n.d.) 
Though relatively expensive, but the Coger management is not sell at prices affordable only for the upper class only. The price of honey Manglayang coffee, which is sold for Rp120 thousand $/ \mathrm{kg}$, when processed in the kitchen of the Coger café, with SCAA - Specialty Coffee Association of America standards, can still be obtained by paying as much as you want. Thus the coffee that is paid in kind is still in accordance with international standards. This shop uses all its shops for the benefit of the people. First, the proceeds from the sale of this coffee are calculated using a profit sharing system. Whether or not the service is good, will depend on how good the management and employees honor customers. Management coffee Coger want anyone entitled to a special service with standat special coffee anyway . Both in terms of compounding and quality.

This café which is set together with in Mualaf Center, also allocate profits to provide compensation to convert to Islam, to fund the construction of mosques, go to the a place to support for those exposed to disasters both in Indonesia and regional conflicts led in other Muslims country.

Historically, Zakat, Sadaqah (charity), Awqaf (endowment) and Qard Al-Hasan (loan not-forprofit) is practiced to reduce poverty in the time of Prophet Muhammad SAW. Among the instruments of poverty alleviation, Coger also operating funds for the needy, support muallaf, channeling aid into the pockets of Christianization, medical assistance affected covid-19 to help humanity. Thus reduce income inequality. (Nusrate Aziz \& Mohamad, 2016)

Although some of them are mandatory and others are optional components, the main target is to support the less fortunate, namely the less fortunate, both financially and exposed to disasters. Poverty alleviation by managing funds through the product and service businesses mentioned above is one of the important goals of the Prophet.

Prophet Muhammad SAW build the foundation framework Islamic Economy is based on the social awareness which prohibits the creation of centralization of wealth. The principles of Islam that are prominent in society are social equality, economic equality, brotherhood and unity, and justice (Shahzad, 2012)

Islam believes that Muslim communities who are financially capable have a responsibility to the poor in their society. Rasulullah SAW said : Not including from my ummah (people) those who were sleeping while his neighbor sleep in hunger. (Kusumaningtyas \& Putranto, 2020)

Islamic economic fundamentals cannot be changed. Therefore the weight of Zakat, Sadaqah, Infaq, Endowments both in terms of their importance and consequences remains the same in the twenty-first century. However, the economic order of Islam, we have some investments that help us grow exponentially charitable assets. Social-based business in the realm of Islam is a sustainable model for solving social problems and alleviating poverty. (Nusrate Aziz \& Mohamad, 2016)

\section{Conventional Business Concepts}

In the conventional theory and empirical studies, gain advantage by maximizing the business is an ideal. In this theory, they tend to ignore the rights of employees, including welfare and justice. Inefficiency of income distribution and wealth are caused imbalance in the society. As a result, in the 1990s, various institutions emerged to strive for businesses that gave employees human rights. 
The emergence of Muslim entrepreneurs which engaged in the social sector was briefly introduced by Steven Indra Wibowo who built this business for the benefit of the ummah as a whole. This coffee business focuses on service products with a profit sharing system for social and da'wah purposes. This coffee shop gives a total business profit to charity. By carrying out the slogan to pay as much as you want, this indicates that this business experiences income that fluctuates every month. The income is divided equally into employee salaries, operations, raw materials of coffee and social movements. This shows a symbiotic mutualism. Management provides barista training to be able to serve the best coffee and service to customers. While customers feel that the coffee they buy has international standard taste, they don't hesitate to appreciate the coffee according to its quality. Not only that, customers who are not satisfied with the service and taste of coffee that are not in accordance with their expectations, they may not pay for the coffee and will be made new coffee again. And this is a note for baristas to provide good waiters with their coffee blends. A good service will motivate customers to appreciate the coffee made. Often high-class customers who know the quality of the coffee will dare to pay dearly. Meanwhile, customers who feel inadequate can pay as much as they want. The shop employee will give the cashier's keyboard for the customer to type himself the number he wants. This is a da'wah value for Kedai Coger that the shop is not a high-class monopoly only because of the quality of the coffee that is processed by SCAA-compliant baristas. But whoever has the right to get the best apelayana regardless of social class. But anyone has the right to get the best service regardless of social class. The goal of the establishment of this coffee shop is Islamic preaching, that every human being has the right to get good service. So that the social barrier does not exist. This management is simple. First, the profit after sharing will be used for reinvestment; therefore the business will flourish. Second, the funds will be used to improve the quality of products or services. Third, part of the funds will be used for social activities, da'wah development and delivery of disaster relief. Thus, Coger's Coffee Shop contributes to economic and social welfare.

Social welfare includes economic welfare, (such as poverty and inequality alleviation), and socio-environmental improvement (through fair trade, production and production that is environmentally friendly by ensuring workers' rights). So Islamic economics based business is a business free of usury and meny $u$ sprinkle the results. Thus, it will maintain corporate social responsibility (CSR) and promote the principle of brotherhood. The business itself and its profits will be used to reduce social problems and alleviate poverty. An endeavor that follows Islamic principles will, in the end, be motivated by the satisfaction of being with Allah SWT . In addition, if it is supported by the existence of Islamic institutions, it can be an effective marketing channel. Marketing channels that are formed naturally are one clear example of a new concept, namely spiritual marketing. (Fahamsyah, 2020)

In 622, the Prophet founded the Islamic state by introducing Zakat, encouraging shadaqah, waqf and to eradicate social problems and poverty. Islam does not allow interest-based transactions (Nusrate Aziz \& Mohamad, 2016) nor does it allow the maximization of personal gain. Therefore, even though Islamic economic business is motivated by profit, like any other general business, it must still comply with the basic principles of Islam, such as practicing Islamic adab, maintaining supply and customer rights, ensuring fair business, prioritizing employee rights and using production that is environmentally friendly.

Economists and social scientists have recognized the capitalist concept of optimizing profits. It cannot solve many social and economic problems. Capitalism has therefore undergone many reforms. In the new economy and finance, moderate capitalists have been looking for a suitable 
approach that will ensure socio-economic development for underprivileged segments of the population.

Neoliberalism theory is used to solve social problems and poverty (Johnson, 1997)As a result, the idea of social enterprises emerged (Yunus, 2009). Although (Kuznets, 1955) discussed the hypothesis of the phenomenon of reducing inequality through encouraging economic growth, he did not suggest any policies for the welfare of underprivileged segments of society. (Yunus, 2009) made the concept of a Social Business problem-solving method regardless of the level of development of a country. Hence, social enterprises focus more on certain social problems . On the other hand, Social Business deals with general problems, such as poverty and inequality, as well as certain problems, such as education for the underprivileged; providing food, shelter, and health support for the hard-core-poor; and supporting charities and orphanages.

In addition, (Freeman, 1984) in stakeholder theory shows that together with the business itself, suppliers, employees, customers, the environment and society are all contributors of a business entity.

Therefore, it needs several company initiatives to be taken by the business world to help them get out of poverty. (Nusrate Aziz \& Mohamad, 2016) assess that all these neoliberal concepts are embedded in the basic principles of Islam, which have been ignored by traditional capitalist societies. Economic Islam emphasizes social equality (all social beings have equal rights in society) and economic justice (everyone is entitled to the minimum required amount of wealth and income necessary for their livelihoods) in society.

Sources of funding (mandatory and optional) to solve social problems, and reduce poverty and inequality are also clearly stated in Islam. The main Islamic instruments for fighting poverty and inequality are Zakat, Sadaqah, Waqf and Infaq . Islamic scholars propose different methods to efficiently utilize these funds. Mass, (Al-Gari, 2004) suggested establishing a non-profit organization. In Indonesia, besides Café Coger, there are also social-based businesses. A doctor named Aznan Lelo who is also a professor at the Faculty of Medicine at the University of North Sumatra (USU) opens a practice without installing a signboard, for his patients he does not charge a fee. Patients pay for consultation services and concoct drugs at will. The prescription for pharmacy drugs is affordable. The patients were only asked to fill the envelope at will. (Kisah Dokter Hebat by Seputar Medan | Medium, n.d.)

(A.M. Sadeq, 1997) shows that the poverty alleviation scheme in Islam is mandatory. In addition, establishing a service center, both products and services, as done by Steven and Aznan is an effective instrument in poverty alleviation.This study suggests a system for growing a charity business. The framework $b$ usiness social integrated with charity Islam could prove be a powerful approach to poverty reduction (Hassan, 2010) suggested that coordination between Zakat and Waqf institutions, government agencies, non-governmental organizations and civil organizations is essential to create a significant impact of charity funds on poverty alleviation. Finding funding is one of the major challenges for business based social. The capitalists are those who are fully motivated by utility and advantages. Economic actors are considered individualistic and selfish people. (M.A. Mannan, n.d.) If a charity-based business can turn individualistic and selfish into cooperative and socially responsible, then this method can be the progress of society in reducing poverty.

Male Muslims (M.A. Mannan, n.d.) are socially responsible and must have Islamic morals. Then a muslim motivated by religion to spend time Sadaqah, Endowments and Infaq.There are 
basically two types of Islamic funding sources for poverty alleviation, namely sources that can be returned and sources that cannot be returned. The source of refundable funds is $Q a r d ~ A l-$ Hasan. However, non-returnable sources can be classified into two categories:

mandatory sources, such as Zakat, and highly recommended but optional sources, such as Endowments and Sadaqah.

There are eight groups of people who are entitled to receive Zakat funds . In fact, zakat is only for the needy, the poor, the administrators of zakat, the converts who are persuaded by their hearts, for (freeing) slaves, people in debt, for the way of Allah and for those who are yuang is on the way, as a decree which Allah obliges, and Allah is All-Knowing, Most Wise. (Quran Surat At-Taubah Ayat 60 Arab, Latin, Terjemahan Arti Bahasa Indonesia, n.d.)

They ask you what they should spend. Say: No matter how much wealth you spend, it is for your parents and close relatives and orphans and needy people and travelers, and whatever good you do, Allah will know it (Al-Quran 2: 215).

(Almsgiving) for the poor trapped in the way of Allah - they a have nowhere to go ; fools think they are rich because (they ) don't do (beg); You can recognize them by the mark; luckily they don't beg from men; and Whatever good things you spend, Allah will know it ( Al-Quran 2: 273).

Progressive taxes can reduce inequality by reducing the wealth of the rich; However, this does not necessarily reduce the poverty level of a community. Taxes on dasarny a is a major source of government revenue could she locations right for alleviating poverty. However, taxes are often not a priority sector for governments in developing countries.

In contrast, there are eight special sectors for Zakat distribution and almost all of them lead to poverty alleviation and inequality reduction if zakat funds are used efficiently.

Fundamental Islamic sources ( Al-Quran and Al-Hadith ) remind a Muslim to often do charity. There are many verses in the Quran that advise Muslims to do good deeds. For example, the following verses from the Al-Quran and Hadith from Al-Bukhari, which strongly encourage Muslims to spend on shadaqah: And fear Allah as much as you can, listen and obey, and spend in alms for your own benefit. Surely those who save themselves from greed are those who achieve prosperity ( Quran 64:16).

Prophet Muhammad said, Every Muslim must pay shadaqah. The follower ask, what about someone who has nothing to give? Prophet Muhammad replied, let him do something with both hands and benefit himself. It will be charity.

Hence, wealthy Muslims are motivated to spend time on shadaqah, which can be productive Social funds from business activities. Usually, people donate buildings or lots of land or even cash for charity purposes. Waqf is usually used to build mosques, to fund the needs and education of orphans, to establish Islamic institutions and so on. Waqf funds are usually held and regulated by charitable trusts. These funds can be used for the benefit of mankind. Waqf has historically played an important role in Muslim society through the establishment of educational institutions, charity hospitals, orphanages and so on (Zidane, 2010)

Waqf may be conditional or not. The Waqif (person who donates) can provide the condition that the waqf asset must be spent on a certain group of people, such as an orphanage. This fund is known as mushrut-ul-khidmat.

Prophet Muhammad SAW also advised his followers to practice Qard Al-Hasan. In Ibn Hisham and Ibn Majah reported that the Prophet Muhammad SAW said, on the mi'raj trip, I looked at the gate of heaven written, reward Sadaqah ten times and the reward for Qard Al-H Assan is eighteen times. Then, I asked the angel, how can this be ? The angel replied, because a beggar who already has something but the borrower does not collect the loan unless he needs it. 
In another Hadith from Sahih Al Muslim, from Abu Hurairah, the Prophet SAW said, whoever frees a mukmin from difficulties in this world, Allah will free him from his difficulties and Allah will facilitate him in this world and in the hereafter. .

If a concept does not contradict the fundamental law of Sharia, we do not need to change that concept. The use of business fund allocations based on Islamic economics must make a significant contribution to poverty reduction. Though these funds can be used to solve other social. So Islamic business should not be limited to solving social problems but also for da'wah purposes. So that it will reduce social inequality. Solve social problems, including building health facilities (drinking water , improvement of nutrition), medical support, education , keep the area prone to apostasy, and clicking solve other social problems in the community.

This is a collective initiative by an Islamic charity managed by a professional business (without the need to continuously raise funds by begging) through the Islamic Economy-based Social Business, which will significantly reduce poverty.

An Islamic charity based business can collect Waqf, Sadakah and Zakat from other people (coffee customers, patients) and public institutions. An Islamic charity business should be able to set up a business for the poor and will provide them with training for SMEs. The poor are given the opportunity to run their business with the given capital so they can become entrepreneurs without depending on others. And the profit will be theirs. An innovative Islamic economy-based social business will give birth to many ideas to alleviate poverty and society

\section{Conclusion}

Social business, social enterprise, stakeholder theory and CSR must have thoughts and innovations that can shift the selfish concept of capitalism into selfless social capitalism. It must be attached to and become the responsibility of every Muslim. One of the teachings of the Prophet Muhammad SAW is that a rich person should not sleep contentedly while his neighbor sleeps hungry. Prophet Muhammad SAW not only ordered the payment of Zakat - which is one of the fundamental pillars of Islam, but also encouraged the practice of Qard Al-Hasan, Sadaqah and Waqf to alleviate poverty. Zakat in Islam is not considered as the contribution of rich Muslims to the poor, but as the right of the poor to the wealth of the rich . This symbiosis must be seen as part of the preaching towards one brotherhood.

Because of religious commitment, the business stakeholders Islam should play a greater role in ensuring kesejahte raan socially and economically through equitable income distribution, airjustice social, environmental balance and increase economic development.

\section{Note}

1. The Quran has, on several occasions, ordered capable Muslims to pay Zakat ( see, eg AlBaqarah: Verses 43, 83, 110, 177). In his last sermon, the Prophet SAW reminded him about Zakat which is a mandatory obligation for wealthy Muslims. Prophet Muhammad SAW said: O People, listen to me earnestly, worship Allah, pray five times a day (Salat), fast during the month of Ramadan, and give your wealth in Zakat. Perform Hajj if you can.

2. Al-Quran states, but God has allowed businesses and forbids riba (interest). Prophet Muhammad SAW stated in the last sermon, O people [...] Allah has forbidden you to taking riba (interest), then all interest obligations are subsequently released. Your capital, after all, it is yours to keep. You will not cause or suffer injustice.

3. Allah says: Those who believe are only one Brotherhood ( Al-Hujurat 49:10). Muslims all over the world are a brother and help one another. Wealthy Muslims have a responsibility to help poor Muslims. In fact, as humans all people are capable of being responsible for helping all mankind. Prophet Muhammad in the 'final sermon' say: The whole human race is from Adam 
and Eve, Arabs had no advantage over a non-Arab nor a non-Arab has no advantage on Arabs; also a white person has no advantage over black and a black person has no advantage over white except by piety and good deeds. Learn that every Muslim is sauda ra to every Muslim and that Musli m constitute one brotherhood.

\section{References}

A.M. Sadeq. (1997). Poverty alleviation: an Islamic perspective. Humanomics, 13(3), 110134.

Al-Gari, M. . (2004). The Qard Hassan Bank, paper presented in the International Seminar on Nonbank Financial Institution: Islamic Alternatives, jointly organized by Islamic banking and Financial Institute, Kuala Lumpur, 1-3 March.

Fahamsyah, M. H. (2020). Spiritual Marketing Gontor dalam Mempertahankan Positioning. TSAQAFAH, 16(1), 147-162. https://doi.org/10.21111/tsaqafah.v16i1.4337

Freeman, R. . (1984). Strategic Managenet: A Stakeholder Approach. Pitman Publishing, Boston, MA.

Hassan, M. K. (2010). An integrated poverty alleviation model combining zakat, waqaf ang micro-finance. Seventh International Conference -- The Tawhidi Epistemology: Zakat and Waqf Economy, Bangia.

Johnson, N. (1997). Lester M. Salamon and Helmut K. Anheier (eds.), Defining the Nonprofit Sector: A Cross-national Analysis, Manchester University Press, Manchester, 1997, xiii + 536 pp., £50.00 hard, £16.99 paper. Journal of Social Policy, 26(4), 543-570. https://doi.org/10.1017/s0047279497315104

Kisah Dokter Hebat by Seputar Medan | Medium. (n.d.). Retrieved November 11, 2020, from https://medium.com/@seputarmedan/kisah-dokter-hebat-dari-medan-yang-dibayarseikhlasnya-sudah-diundang-kick-andy-dua-kali-6d9bbc2aa7df

Kopi Manglayang Tembus Pasar Maroko, Jepang, Australia - Ekonomi Bisnis.com. (n.d.). Retrieved November 10, 2020, from https://ekonomi.bisnis.com/read/20180702/12/811670/kopi-manglayang-tembus-pasarmaroko-jepang-australia

Kusumaningtyas, M., \& Putranto, J. (2020, May 20). Does Sharia Coffee Business Development Influence Employee's Welfare? Proceedings of the Proceedings of the 1st Conference on Islamic Finance and Technology, CIFET, 21 September, Sidoarjo, East Java, Indonesia. https://doi.org/10.4108/eai.21-9-2019.2293969

Kuznets. (1955). Economic growth and income inequality. American Economic Review, 45 No.1, 1-28.

M.A. Mannan. (n.d.). Islamic Economic: Theory and Practice: A Comparative Study,. Sh Muhammad Ashraf Publishers, Lahore.

Matthew Lewin wins 2019 Australian Barista Championship! - ONA. (n.d.). Retrieved November 10, 2020, from https://onacoffee.com.au/news/matthew-lewin-wins-2019australian-barista-championship/

Nusrate Aziz, M., \& Mohamad, O. Bin. (2016). Islamic social business to alleviate poverty and social inequality. International Journal of Social Economics, 43(6), 573-592. https://doi.org/10.1108/IJSE-06-2014-0129

Quran Surat At-Taubah Ayat 60 Arab, Latin, Terjemahan Arti Bahasa Indonesia. (n.d.). Retrieved November 11, 2020, from https://tafsirweb.com/3076-quran-surat-at-taubahayat-60.html

Riad Diharja. (2018). Perencanaan dan Perancangan Pusat Penelitian dan Pengembangan 
Tanaman Kopi. Tema: Green Arsitektur untuk Kesegaran Ruang. Skripsi Universitas Pendidikan Indonesia.

Shahzad, S. (2012). Social enterprises and Islamic society: the role of Islamic financial institutions. Islamic Finance Review ISFIRE, August, 36-39.

Yunus, W. K. (2009). Creating a World without Poverty: Social Business and the Future of Capitalism. United States by Public Affairs, New York, NY.

Zidane, M. E. . (2010). Point of view: an Islamic perpective on social business. New Horizon, $174,16-18$. 